to the brothers-farmers. On the idea and organization of Ukrainian monarchism]. Viacheslav Lypynskyi ta yoho doba - Viacheslav Lypynskyi and his era. Ostashko T. Tereshchenko Yu. (Ed.). (Vol. 1, pp. 92-214). Kyiv Tempora [in Ukrainian].

9. Renan, E. (2008). Scho take natsiia? [What is nation?] Natsionalism : Antolohiia - Nationalism: Anthology. Protsenko O., Lisovyi V. (Ed.). (pp. 253-263). Kyiv : Prostir, Smoloskyp [in Ukrainian].

10. Alter, P. (2008). Natsiia : problema vyznachennia. [Nation : the problem of definition]. Natsionalism : Antolohiia Nationalism : Anthology. Protsenko O., Lisovyi V. (Ed.) (pp. 273-282). Kyiv : Prostir, Smoloskyp [in Ukrainian].

11. Prysiazhniuk, Yu. (2013). Poniattia «narod» u retrospektsii ukrainskykh i polskykh intelektualiv XIX st. [The concept of «people» in retrospect of Ukrainian and Polish intellectuals of the $19^{\text {th }}$ century]. Rozdró̇a. Polsko-ukraiński dyskurs humanistyczny. Częstochowa ; Humań ; Poznań Wydawnictwo «Taurus», 201-208 [in Ukrainain].

12. Prysiazhniuk, Yu. (2008). Istorychna svidomist ta mentalnist ukrainskykh selian na zlami XIX - XX st. [Historical consciousness and mentality of Ukrainian peasants at the turn of the $19^{\text {th }}-20^{\text {th }}$ century]. Historia - mentalnośc - tożsamość. Miejsce $i$ rola historii oraz historyków w życiu narodu polskiego $i$ ukraińskiego $w$ XIX $i$ XX wieku. Pzeszów : Widawnicnwo uniwersytetu Pzeszówskiego, 348-355 [in Ukrainian]

13. (1909). Demoralizatsia ukrainskoho sela. [Demoralization of the Ukrainian village]. Rada - Council. № 263, 1 [in Ukrainain].

14. (1910). Vony ne prosiat? [They do not ask?] Rada-Council. № 19, 1 [in Ukrainian].

15. B. Hrinchenko - M. Drahomanov. (1994). Dialohy pro ukrainsku natsionalnu spravu. [Dialogues about the Ukrainian national affair]. Kyiv : Institute of Ukrainian Archeography National Academy of Sciences of Ukraine [in Ukrainian].

\section{O. Ostrovskyi}

\section{PEASANTS BECOME... COSSACKS (TO THE HISTORY OF THE KHOLODNYI YAR EXPERIENCE OF NATIONAL LIBERATION STRUGGLES DURING THE PERIOD OF THE UKRAINIAN REVOLUTION OF 1917-1921)}

Introduction. The problem, which the author formulates and tries to solve at least partially in this article, concerns historical processes of formation of modern nations in Europe and, in particular, in the countries of its eastern part. Guided by the established norm in modern humanities that the formation of existing modern nations "was not inevitable», he tries to trace the process of transition of «no» nation to «its existence» on the example of Ukrainian historical experience of the first quarter of the twentieth century. This experience can't be considered positive or negative. The fact is that many variants of the Ukrainian modern creation of the nation gave, so to speak, a «half» result. These include, apparently, the vector of development, which is described as "peasants become Cossacks». Taking as a basis the thesis that the central theme of the twentieth century there is transformation of the ethnos into a conscious political and cultural community (which is already substantiated in historiography), the author tries to consider this version of the nation.

Purpose. The purpose of the article is to try to clarify the essence of the Cossack version of the creation of the Ukrainian modern nation (state) on the experience of the struggle of the insurgents of the Kholodnyi Yar era of the Ukrainian Revolution of 1917-1921.

Methods. The basis of the methodology of scientific research is an interdisciplinary approach that allows imagining, creating and analyzing the scientific picture of the world; it also helps to identify similarities and differences, as well as features and interactions of peoples and social groups.
Results. Based on the events of the Kholodnyi Yar, the author formulated a concept motivated by the desire to find a "Cossack trace» in them. To this end, he focused on such cognitive positions as: first, was the Cossack "public» movement really national or not? second, was the peasantry the object of the spread of this movement, or at least to some extent participated in it as a subject? third, most importantly, what was (if any) Cossack in this movement, other than name? The biographies of the direct participants prove that the Kholodnyi Yar movement was Cossack, but not entirely «public» (not peaceful), national, but limited by regional priorities.

Originality. Prospects for the Cossack version of the creation of the Ukrainian modern nation in the experience of the struggle of the insurgents of the Kholodnyi Yar were extremely limited. First of all, because the historical memory of the Cossacks had already been lost by the Ukrainian elites, and its new generation, co-opted mainly from the intelligentsia, didn't see in the peasantry a "Cossack» revolutionary potential. This did not mean the same oblivion in the people themselves. However, "underneath» initiatives were clearly lacking for large-scale change, as regional movements could not ensure ultimate success.

Conclusion. The study showed that the Cossacks of the first quarter of the twentieth century, as a kind of modern national self-affirmation of Ukrainians, more resembled the freemasonry of Koliivschyna thah the Bohdan Khmelnytskiy Zaporizhzhia Army state.

Key words: early modernism, Cossacks, people, modern nation, insurgents, revolution, state.

\section{УДК 94:341(323.12)(058.232)«19» \\ DOI: 10.31651/2413-8142-2020-24-Prysiazhniuk}

Ю. П. Присяжнюк доктор історичних наук, професор, професор кафедри історії України Черкаського начіонального університету імені Богдана Хмельнииького ORCID: http://orcid.org/0000-0001-8324-4681

\section{УКРАЇНСЬКІ СЕЛЯНИ ПОЧАТКУ ХХ СТ. У КОНТЕКСТІ ВИКЛИКІВ ПРИЙДЕШНЬОЇ ЕПОХИ: МІЖНАРОДНИЙ АСПЕКТ}

Досліджено проблему причетності українського селянства до прочесів, які визначали суть $і$ характер начіональної та світової трансформачії суспільства початку - перших десятиліть $X X \mathrm{~cm}$. Інтерес до иієі проблеми продиктований спробою глибше прояснити взаємозалежність традииійного (сільського) та модерного (урбанізованого) середовищ на етапі творення тих форм самоствердження й комунікації, які були приманні людям/спільнотам тієі доби. Спираючись на власні, a синхронно тематично близькі та альтернативні за інтерпретаційними положеннями студії, автор приходить до висновку, щзо саме національнодержсавницькому поступу судилося стати єдиною гідною відповіддю на питання міжнародного визнання украӥнців.

Ключові слова: геополітика, історіографія, ментальність, етнічна самобутність, селянська начія, традииійне суспільство, модернізаиія.

Постановка проблеми. Модерна історія українців увсіхії суспільних виявах, інтелектуальних уявленнях та інтерпретаціях, передусім як історія етнічна, національна, державна, діаспорна, релігійна, культурна, міжнародна тощо на зламі 
Селянство Украӥни та Європи за умов сочіально-економічних та суспільно-політичних трансформацій другої половини XIX $-X X \mathrm{~cm}$.

XIX - XX ст. зазнала радикальних змін. Це було спричинено багатьма чинниками, найпотужніші 3 яких виявилися тісно пов'язаними з глибокими й направду глобальними пертурбаціями світового масштабу.

3 огляду на нинішній стан історіографії, ще далеко не повною мірою можна збагнути, як на тогочасних сільських людей впливала політика провідних державах, передусім відчутне посилення державного регулювання економіки, тобто системні заходи законодавчого, виконавчого та контролюючого характеру, що їх здійснювали державні інституції та громадські організації 3 метою стабілізації й пристосування господарства до нових історичних умов. Наголосимо, що якраз у той історичний період 3'явилася можливість державного регулювання економікою, що було зумовлено новими явищами, передусім небаченою раніше концентрацією виробництва й капіталу. Власне на цій основі поглибився суспільний поділ праці, який уперше сягнув світових масштабів. Він покликав до життя феномен планетарної економіки, беручи ширше, глобального світу. Це означало, що люди, які мешкали на різних континентах, ставали більше взаємозалежними, але водночас зростали й суперечності між провідними державами, бо політичне життя кожної 3 них зазвичай «обслуговувало» не світову потреби, а національні інтереси.

У зв'язку 3 «першою хвилею» світової глобалізації, яка припала якраз на початок XX ст., наростали незнані до того труднощі й завданням державних лідерів ставало їхне вирішення. Є підстави вважати, що метою таких зусиль було стимулювання економічного зростання, протекціоністська політика, збереження вже контрольованих ринків і сфер впливу, регулювання рівня зайнятості населення, заохочення прогресивних змін.

3 огляду на предмет пропонованого дослідження, нашу увагу більше привертають країни, так би мовити, «другого порядку», а саме ті, які «не володіли світом», тобто не були потужними метрополіями, а десь навпаки - намагалися ствердитися як «повноцінні» (незалежні) національні держави. Відтак акцент дослідження зміщуємо на геополітичні особливості Східної Європи, у реаліях якої українці, передусім їхня інтелектуальна та політична еліта, прагнули реалізувати власні національні проєкти. Свою роль у цих процесах судилося відіграти багатомільйонному селянству, яке визначало не лише етнічне, а й національне обличчя української спільноти.

Аналіз останніх досліджень і публікацій. Аби краще розуміти процеси, що відбувалися в Наддніпрянщині, яка належала Російській імперії i своєю чергою поділялася на кілька регіонів зі своїми історичними особливостями кожний, i де мешкали переважно українці, що зберігали свою культуру й історичну пам'ять, доречно бодай коротко зупинитися на історіографії явищ, які становили сутність тогочасного суспільного контенту.

Історики по-різному пояснюють і оцінюють його. Найпоширенішими моделями (метафорами), які прийнято використовувати для його трактування, $\epsilon$ поняття «індустріальне суспільство» та «модерне суспільство». Якраз вони «задають» сьогодні історикам і всім гуманітаріям логіку пояснення, яка не лише визначає алгоритм очікуваних результатів, а й поважно впливає на відбір та інтерпретацію джерел, характеристику державних рішень, тлумачення громадських настроїв, долю відомих історичних постатей, «перспективи боротьби» широких верств населення. У такий спосіб сучасні гуманітарії (зрозуміло, що не всі 3 них $є$ однодумцями) ніби прийняли естафету, яку свого часу, ще в добу Романтизму, запровадила французька історіографія. Водночас вони послуговуються метафорою «уявлені спільноти» (imaginet community), яку 1983 р. ужив Бенедикт Андерсон на позначення процесів націотворення, і яка «впевнено прижилася у сучасних студіях над націями та націоналізмами» $[1,5 ; 2,37]$.

Зважаючи на ту обставину, що селянство вкрай рідко потрапляло в контекст аналізу міжнародних відносин початку XX ст., принагідно звернемо увагу на особливості, які пов'язані з регіональною специфікою. Якщо під індустріалізацією в іiі вузькому значенні розуміти пришвидшені темпи розвитку важкої промисловості на тлі прогресивного поступу всього господарського комплексу, то власне великий регіон підросійської України виглядає тут виграшно. Як справедливо зазначає О. Шляхов, на відміну від Східної Галичини, Північної Буковини та Закарпаття, він успішніше «індустріалізувався», насамперед через кращі «стартові умови» (наявність корисних копалин та ін.) та інтеграцію всього «півдня Росії» (Наддніпрянщини разом з Північним Кавказом) в загальноімперський поділ праці [3, 29]. Принагідно зазначимо, що крім О. Шляхова, різних аспектів «внеску» селянства в міжнародний аспект суспільних трансформацій у своїх працях в останні десятиліття торкалися Я. Бойко, Я. Грицак, О. Житков, Л. Зашкільняк, Г. Касьянов, С. Корновенко, В. Крутіков, М. Костюк, О. Михайлюк, О. Приймак, О. Реєнт, В. Сарбей, Ф. Турченко, I. Фареній, С. Шамара, В. Шевченко, М. Якименко. Відбір дослідників до запропонованого списку зумовлений інноваційними ідеями та особливостями їхнього наукового доробку.

Метою розвідки $\epsilon$ дослідити вплив змін світового порядку, передусім у соціально-економічній і національній сферах, на перспективи трансформації селянства Наддніпрянщини початку XX ст., його ролі в прийдешній історії.

Виклад основного матеріалу. Попервах доречно наголосити, що історичний розвиток Наддніпрянщини, хоча й із помітними відмінностями, проте цілком збігався із тенденціями світового поступу. Зокрема й щодо згадуваної концентрації виробництва - зосередження господарських потужностей у руках окремих власників. Цю концентрацію виробництва, як згодом і капіталів та робочої сили на великих підприємствах, ніхто не планував i не прогнозував, кажучи інакше, вона відбувалася природно. Унаслідок цих змін на рубежі XIX - XX ст. виникли історично нові типи господарювання - великі об'єднання, що постали 3 метою одержання надприбутків. Вони отримали 
назву «монополії». Власне монопольне право виявлялося на ринку, тобто у збуті продукції, де до того існувала конкуренція.

Є підстави стверджувати, що наддніпрянці були причетними до всіх типів одногалузевих монополій початку $\mathrm{XX}$ ст. Їхньою місцевою специфікою було переважання другого типу - синдикатів, а «воротилами бізнесу» часто-густо були не українці, яких, до речі, мало було і серед робітників [3, 30]. Ще однією особливістю стало існування двох історичних етапів індустріалізації. Перший - природний - розпочався орієнтовно в 1890-х pp. Проте буде ще й другий етап, так би мовити, «штучний» (або «політичний»). Справа в тому, що переходом більшовиків до економіки, грунтованій на державній («соціалістичній») власності на засоби виробництва, виникне потреба визначати хід господарського розвитку в «ручному режимі». Його назвуть «ленінським планом будівництва соціалізму». I хоча В. Ленін такого плану не заповідав (він помре в січні 1924 р.), саме під цією назвою новий партійний вождь Й. Сталін почне «впроваджувати» його 3 кінця 1920-х рр. у формі так званих «п’ ятирічних планів». Ключовою ланкою нових змін якраз і стане індустріалізація, хоча, добре відомо, що в провідних країнах світу вона успішно відбуватиметься і «на капіталістичній основі» [4, 14]. Відтак штучна сталінська індустріалізація «доопрацює» те, з чим історично «не впоралася» іiі попередниця - природна індустріалізація.

Пропонуючи такий алгоритм трактування історії індустріального суспільства в Україні, спонукаємо читачів до думки про потребу послідовної деміфологізації існуючих дотепер історіографічних дискурсів, у яких політиці все ще належить домінуюче становище. Тут відкриваються перспективи не лише краще розуміти власне індустріальне суспільство, а й на продуктивній епістемологічній основі інтерпретувати саму політичну історію. Тобто, політика - цей колишній суб'єкт історії - має «виграти» від того, що вона повертається до свого природного стану об'єкта iсторії.

Невід'ємною складовою індустріального розвитку було формування нових соціальних верств («класів») - буржуазії (підприємців) та робітників (пролетаріату). Совєтські історики багато уваги приділяли цій проблематиці. В обов'язковому порядку керуючись постулатами марксистськоленінської ідеології, вони часто зводили всю сутність капіталізму до характеристики виробничих відносин «між капіталом і працею». I вже на цій основі пояснювали все решту, включно й так звану «надбудову» - політику, мораль, релігію, сімейно-шлюбні взаємини, «відокремлення міста від села» та ін. $[5,44]$. Не вдаючись до розлогої характеристики й, відповідно, затребуваної станом сучасної гуманітаристики та постгуманістики комплексної критики матеріалістичного розуміння iсторії, у контексті нашої тематики зазначимо, що в такий спосіб дещо неприродно виглядав зв'язок між Україною, загалом Російською імперією i Заходом, включно з США та Японією. Виходило так, що концептуальне розуміння світового історичного процесу, як він відбувся на початку XX ст. і тривав надалі, треба було в обов'язковому й нерозривному контексті поширювати на досвід України. Власне тому вона відразу отримувала статус «залежної та відсталої провінції», що на свій лад задовольняло як російського (совєтського) «політичного замовника», так i, опосередковано, «неупередженого західноєвропейського читача» $[6,27]$. Обоє мали втішатися 3 того, що країна 3 великим економічним потенціалом, яка географічно розташована в центрі Європи, водночас і належала до їхньої історії, i, що дуже імпонувало, ніби не претендувала на власне національно-державне самоствердження, могла бути своєрідним донором для підсилення їхніх прагнень.

Зважаючи на ту обставину, що до XX ст. наслідком урбанізації стало кількісне переважання робітників у соціальній структурі суспільства країн Заходу, совєтські історики намагалися будь-що «наздогнати» цю тенденцію 3 огляду на завдання інтерпретації суттєво інакших реалій Російської імперії. Виконуючи в такий спосіб цілком конкретне замовлення, вони всіляко перебільшували роль «робітничого класу» і в історії України, уперто не помічаючи, що ситуація в країні на берегах Дніпра виглядала відмінною і від «строкатого» Заходу, і «багатоликого» Сходу [7, 280].

Такий стан історіографії проблеми спонукає ще раз звернути увагу на (не)бажання етнічних українців другої половини XIX - початку XX ст. працювати на новобудовах індустрії. Російський дослідник О. Міллер наголошує зворотне, мовляв, «прив'язаність селянина до його «української» землі... не варто міфологізувати. Місто в період, що його досліджуємо, просто не створювало достатньо робочих місць, які могли бути зайняті вихідцями 3 села. Проте число українських переселенців на вільні землі на сході імперії вже до революції 1917 р. наблизилося до 2,5 млн осіб, тобто склало майже 14\% всіх українців імперії» [8, 232]. На нашу думку, загалом аргументовані міркування О. Міллера хибують низкою недоліків.

По-перше, коли мова заходить про факт міфологізації поглядів сільських людей Наддніпрянщини XIX - початку XX ст., історику варто робити акцент не на етнічному (чи національному) терміні «українська», а на базовому для уявлень самих хліборобів понятті «земля» [9, 56-58]. Тобто ситуацію варто розуміти так, що не селяни творили національний міф, позаяк це взагалі була не їхня історична місія, а інтелектуали, які, не важко збагнути, так чи так брали до уваги особливий ментальний світ місцевих хліборобів, які $з$ діда-прадіда мешкали на чи не найродючіших у світі чорноземах із відповідними природнокліматичними умовами, геополітичними та іншими взаємовпливами. Ця оригінальна даність витворила направду особливий i виключно 3 політичних мотивів непомітну для сусідів-росіян етнічну рису - «своєрідну еклектичну суміш східного, західного та американського індивідуалізму» [10, 217]. Ось як переконливо пишуть про нього психологи О. Донченко та Ю. Романенко: «Щодо України природа розпорядилася щедро, і навіть зверх того. 
Селянство України та Європи за умов сочіально-економічних та суспільно-політичних трансформацій другої половини XIX $-X X \mathrm{~cm}$.

М'який збалансований клімат, родюча земля, багаті природні надра, водні та лісові ресурси - все це було і $є$ доброю передумовою для розвитку етносу (! - Ю. П.), формування стабільної психокультури, не репресованої боротьбою за виживання» [10, 207]. Уточнимо лише, що боротьба таки буде, до того ж досить запеклою, але її сферою будуть інші царини людського буття - політична й геополітична.

По-друге, варто брати до уваги масовий міграційний рух, який досліджений у працях багатьох науковців, до яких належать черкасець Ярослав Бойко та полтавець Микола Якименко [11-12]. Пошук вільних земель на окраїнах Російської імперії свідчив не про втрату селянами «національних почуттів», про прагнення вирішувати свої нагальні соціально-господарські проблеми. Спекуляції ж на приписуванні людям традиційного суспільства модерного мислення засвідчують факт присутності в таких дискурсах політичних мотивів. Щоправда, стверджувати, що селяни були цілком байдужими «до краю» (Наддніпрянщини) також не зовсім правильно, хоча зі зрозумілих причин цей погляд варто розуміти виключно в контексті локальної (сільської, окружної) ідентичності.

Не все так однозначно і 3 третім аспектом проблеми, про який пише О. Міллер. На наш погляд, практика 3 легкістю «перетворювати селянина на робітника», яка притаманна російській історіографії, - це вияв ознак своєрідної традиції розуміти представників «трудового народу» суто у візії виробничої сутності, залежності й доцільності. Глибокий аналіз, метою якого був пошук та обгрунтування серйозних альтернатив цій усталеній традиції, засвідчує: уклад селянства, тобто абсолютної більшості етнічної спільноти, як історично стійкий життєвий абсолют, ще довго «виявлятиме свій традиційний характер» [13, 541]. Хоча вже тоді й традиційний уклад, і характер потребували «значного підвищення рівня... цивілізованості (модернізації - Ю. П.), глибокого фундаментального впорядкування... міжсуб'єктних стосунків усередині соціуму» $[10,224]$.

3 огляду на запропоновані уточнення щодо інтерпретації готовності українців рубежу XX ст. до викликів прийдешньої епохи, нашу увагу привертають студії запорізьких істориків Федора та Галини Турченків. 3 певним застереженням вони визнають той факт, що в південних губерніях Наддніпрянщини «проект Новоросія» був реалізований лише «у його промисловій частині», що підтверджує вищезазначене [6, 27]. Коли ж ідеться про «інтенсивну індустріалізацію регіону» Півдня України, то звернуто увагу на «порівняно низьку питому вагу міського населення» [6, 28]. Серед іiї причин дослідники назвали індустріальний рівень розвитку регіону, який, утім, не «набув всебічного, економічно-збалансованого характеру» $[6,30]$.

Рефлексію українців початку XX ст. на виклики епохи можна простежувати в альтернативних методологічних парадигмах. До однієї 3 найпродуктивніших сьогодні належить концепт модернізації. Він досить зручний для аналізу саме української спільноти, бо вона, як жодна інша на теренах Центрально-Східної Свропи, позначалася потужним пластом культури традиційного суспільства. Кажучи інакше, спільнота, яку на 80-90\% репрезентувало патріархальне за своїми історичними характеристиками селянство, надто некомфортно вписувалася в реалії, де поведінка людини мала бути зумовлена економічною доцільністю, чинними законами (державним регулюванням), гнучкими соціальними структурами та громадсько-активними самоврядними організаціями. Такий стан справ виглядав би не як відсталість, а радше як самобутність, якби якісно інакшою була ситуація 3 національною елітою. Власне того прошарку, який був покликаний творити, очолювати, репрезентувати й аналізувати нову історичну якість суспільства.

Актуалізованим багатьма обставинами та тенденціями розвитку нового світового порядку виявився саме національний чинник. Якщо відійти від сприйняття першої, а десь і другої половини XIX ст., «як століття формування української національної самосвідомості», ще можна, то стосовно початку XX ст. таке заперечення буде недоречним. Принагідно все ж віддаємо належне здобуткам XIX ст., позаяк «синтез ментального та соціально-економічного», яким оперує сучасна українська та зарубіжна історіографія, «може бути доволі продуктивним, особливо відносно того часу, коли на арену виходив homo economicus» [14, 702]. Цей синтез дає нагоду відчути оригінальне співвідношення комфорту та відповідальності різних суб'єктів історичної трансформації в той період, коли політизація суспільних процесів реально втягувала у свою орбіту більшість населення i багато представників селянства вже не могли задовольнятися становищем людей традиційного суспільства.

Як справедливо зазначає дніпровська дослідниця Т. Литвинова, у пізнавальному ракурсі ця проблема виглядає так: «...Саме розгляд селянського питання у широкому розуміння поняття показав, що часто несвідомо, мимоволі, просто своїм повсякденним побутуванням, господарськими устремліннями, обумовленими потребами часу, малоросійське дворянство закладало підвалини під те, що називають «українським національним відродженням»» [14, 702]. До сказаного додамо, що крім дворянства, таку ж місію виконуватиме і той прошарок, який ми ідентифікуємо терміном «інтелігенція», а західні колеги - «інтелектуали». Долучаючись до дискусії, яку Т. Литвинова запропонувала навколо міркувань, що їх свого часу сформулював I. ЛисякРудницький, додамо: творення національної самосвідомості та ідентичності українців вочевидь відбувалося різними шляхами. Якщо погодитися 3 розмислами, що в основі творення епохи модерності лежала «ідея соціальної взаємодії у першу чергу всіх некозацьких груп населення», підставою чого слугує факт відсутності «повноцінного» козацького середовища в XIX ст., і це надає розмислам T. Литвинової логічної структури й упорядкованості, то ідеї I. Лисяка-Рудницького варто розуміти не як альтернативу, а радше 
своєрідне доповнення до сказаного (з урахуванням того, що вони були оприлюднені набагато раніше) [14, 702-703]. Місію творення «ланки тяглості між козацькою та новітньою Україною» свідомо виконала саме національна інтелігенція, до того ж радше не всупереч, а на продовження того, що «несвідомо» зробило дворянство. I відбулося це вже у другій половині XIX - на початку XX ст., тоді як «націотворча» місія дворян завершилася раніше, орієнтовно в середині XIX ст.

Філософи стверджують, що люди «змінюються зсередини», тому те, що відповідає їхнім пізнавальним потребам в один історичний період, стає непотрібним в інший. Власне через цю причину традиційна культура селянства мало що значитиме в умовах Першої світової війни, революційних потрясінь, не кажучи вже про перший досвід більшовицького експерименту. Ці умови змінюватимуться так радикально, що традиційний устрій виявиться мало дієвим. По суті українство, репрезентоване селянським загалом, перебуватиме в тому становищі, коли воно, з одного боку, довго й болюче прощатиметься зі своєю патріархальною культурою, 3 іншого, вона швидко ставатиме непотрібною.

Ключова проблема полягатиме не в неспроможності адаптуватися у новий світ, який, до того ж, сам переживатиме глибокі пертурбації, а в рефлексії на ті виклики, що були пов'язані 3 альтернативами самих модерних змін. Українство входитиме у XX ст., зберігаючи готовність до локально-половинчастих способів вирішення історичних завдань. Як зазначає британський історик Е. Вілсон, навіть цілі родини, які покликані були уособлювати національний дух та поступ, «часом виявлятимуться поділеними» [15, 167]. I наводить такий приклад. Серед Шульгиних, нащадків полтавського козацького роду, відомими українофілами стануть історик Яків Шульгин та його син Олександр - міністр закордонних справ у недовговічній незалежній Українській Державі П. Скоропадського; натомість їхні найближчі родичі - засновник відомої київської українофобської газети «Киевлянин» Віталій Шульгін (рідний дядько Якова) та його син Василь будуть «послідовними російськими монархістами, людьми з показовим великодержавним мисленням, відповідно відвертими українофобами» [15, 167]. I це попри ті обставини, що всі вони мали спільне родове походження, приблизну однакову освіту, схожі професії. Е. Вілсон уточнює: «Всередині самого українського руху радикальний націоналізм співіснував із поміркованим народництвом та імперським роялізмом, до того ж останній переважав. У 1914 р. більшість українців усе ще належала до типу Степана, а не до типу Оксани, - героїв п'єси Лесі Українки «Бояриня»»» $[15,167]$.

Отож, ми свідомо виділяємо проблему «двох неспроможностей» початку XX ст. Перша 3 них полягала в неготовності українців до творення національної «моно-більшості» й на цій основі вирішення національного питання за прикладом сусідів Центрально-Східної Свропи. Друга, вочевидь, це неадекватна політика «державних» росіян, котрі виявляли до України «чимале невігластво, порівняно з Польщею чи Фінляндією» $[15,167]$

Не викликає особливих заперечень наукове положення, що основними «опозиційними» суспільно-політичними доктринами європейських країн перших десятиліть XX ст., що отримають відоме історичне продовження, стануть соціалізм i націоналізм. Перший, як ліва ідеологія, був покликаний до життя процесами модернізації на етапі втягування у велику політику селянства та іншого «трудового елементу», другий, як права ідеологія, здебільшого спричинений завданнями формування та консолідації національних еліт. Обидва виявилися напрочуд актуальними для власне східноєвропейських народів.

Якщо більш предметно оцінювати готовність українців до викликів прийдешньої (модерної, глобальної) епохи, то наш інтерес до кількісного та якісного зростання інтелігенції вповні виправданий. В Україні ця верства була багатонаціональною 3 помітним переважанням i домінуванням в окремих регіонах росіян, поляків, угорців, румунів. Українців у середовищі інтелігенції було порівняно мало. Серед 127 тис. осіб, які, згідно з Першим Всеросійським переписом населення 1897 р., так чи так «були пов'язані з розумовою працею в 9 губерніях (Наддніпрянщини. - Ю. П.), українців було менше третини» $[6,49]$. Зосереджені вони були здебільшого на Лівобережжі (понад 40\%), тоді як на Правобережжі й Півдні приблизно по 20\%.

Якісна характеристика українських інтелектуалів виглядала ще сумніше. Справа в тому, що вони переважали «серед сільської інтелігенції та спеціалістів без вищої освіти» [6, 49]. I хоча бажаючих ставати вчителями, лікарями, юристами, агрономами ставало дедалі більше, проте «конкуренти» 3 російського, єврейського, польського та деяких інших етнонаціональних середовищ і наділі «тримали першість...» $[16,15$ 16]. Крім того, далеко не всі, хто переходив із селян «у пани», прагнули зберегти етнічну ідентичність. Тут не можна не згадати наслідків русифікації, яку насаджували всі російські імператори, до Миколи II включно.

Завдання консолідації української спільноти і в такий спосіб ствердження іï серед народів (націй) світу було набагато складнішим, аніж здається попервах. Окрім проблем «селянськості», вона мала подолати так звані «національні розриви», які виникли до початку XX ст. Австрійсько-російський імперський кордон, що провокував перспективу Габсбурзької альтернативи, був тут далеко не єдиною серйозною перешкодою. До того часу міграційні процеси призвели до появи не лише українських анклавів на теренах (окраїнах) Російської імперії, а й за кордоном. Сформувалася діаспора. Як зазначає Е. Вілсон, до початку XX ст. «русинські» (галицькі) емігранти розсіялися «по всіх усюдах»: в Австралії, Аргентині та Бразилії, але найбільше їх опинилося а Північній Америці-США та Канаді $[15,195]$. Вони, як це зазвичай буває у цивілізованих народів, допомогли зберегти етнічну та національну ідентичність. Можна більш-менш впевнено стверджувати, що саме західна 
діаспора відіграє ключову роль зовнішнього чинника модерного поступу України, бо «східні українці» виявляться дуже вразливими до асиміляції новою совєтською культурою.

На початку XX ст. українські галичани розвинули потужний місцевий націоналізм, що грунтувався на визнаних здобутках епох Просвітництва, Романтизму та Реалізму, а 3 кінця XIX ст. уже був представлений партійним рухом модерного європейського зразка. Цей націоналізм окреслював і стверджував ідентичність русинів у їхньому протистоянні з місцевими поляками та іншими народами, водночас, долаючи імперські кордони (передусім завдяки творчості й публічної діяльності П. Куліша, О. Кониського, Ю. Бачинського, I. Франка, Лесі Українки, М. Грушевського та ін.), претендував на загальноукраїнську об'єднуючу роль. I все ж тривалий час ситуація була настільки непередбачуваною, що навіть у революційному 1905 р. М. Грушевський висловлював побоювання щодо перспектив «дроблення української нації»: «Українці, як і серби та хорвати, можуть створити дві національності на одній етнографічній базі» $[17,380]$.

Висновки. На міжнародні виклики початку XX ст. українці могли відповісти лише шляхом виконання кількох завдань, які їм лишило попереднє століття й диктували нові історичні умови. Вирішення цих завдань потребувало надзвичайних зусиль і ще довго, аж до кінця XX ст., вони не зможуть похвалитися переможним результатом.

На зламі XIX - XX ст. українство було представлене здебільшого селянством, яке, попри помітні еволюційні успіхи в умовах капіталізації всіх сфер життя, значною мірою лишалося традиційним. Прошарок урбанізованих людей найманої праці (робітників), торговельно-промислової буржуазії українського походження та ідентичності був недостатньо численним i тому маловпливовим. Місто лишалося «чужим» селянству і таким же побічним йому було все, що від нього йшло. Виразніше ці розбіжності спостерігалися у південних і правобережних губерніях.

Спираючись на власні, а синхронно тематично близькі та альтернативні за змістом студії, маємо підстави окреслити проблему, яку прийнято пов'язувати 3 міжнародними перспективами національного життя. Погляди дослідників тут поділяються щонайменше на дві позиції: одні вважають, що центральною темою XX ст. було постання нації, трансформація етнічної маси у «свідому» політичну спільноту, другі навпаки - не вірять у фаталізм «української долі», а утворення нації, як ми іiі уявляємо на початку XXI ст., нібито зовсім не було неминучим. Проблема направду виявилася настільки складною, що навіть такі потужні провісники та організатори національно-державного ствердження українців як М. Грушевський демонструватимуть певну непослідовність. Проте досвід національновизвольних змагань, зокрема Української революції 1917-1921 рр., виявиться вкрай затребуваним для здобуття Україною державної незалежностінаприкінці XX ст. У будь-якому разі лише так удасться зберегти оригінальну (селянську) культуру, мову, традиції, претендувати на гідне своїй історичній минувшині місце в сучасному світі.

\section{Список використаної літератури та джерел:}

1. Андерсон Б. Уявлені спільноти. Міркування шодо походження й поширення націоналізму. Київ : Критика, $2001.272 \mathrm{c}$.

2. Яковенко Н. Довге чвертьстоліття модернізації. Укр. гум. огляд. Вип. 12. Київ : Критика, 2006. С. 37-47.

3. Шляхов О. Б. Царизм та економічна модернізація України (друга половина XIX - початок XX ст.). Вісник Дніпропетровського національного університету. Серія : Історія та археологія. 2008. Вип. 16. С. 29-39.

4. Вебер М. Протестантська етика і дух капіталізму / пер. 3 нім. О. Погорілого. Київ : Наш Формат, 2018. 216 с.

5. Маркс К., Энгельс Ф. Фейербах. Противоположность материалистического и идеалистического воззрений // Маркс К., Энгельс Ф. Избр. произв. В 3-х т. Т. 1. Москва : Политиздат, 1986. С. 4-76.

6. Турченко Ф. Г., Турченко Г. Ф. Південна Україна : модернізація, світова війна, революція (кінець ХІХ ст. - 1921 р.) : історичні нариси. Київ : Генеза, 2003. 304 с.

7. Куций I. Цивілізаційні ідентичності в українській історіографії кінця XVIII - початку XX ст. : між Слов'янщиною та Європою : монографія. Тернопіль : Підручники і посібники, 2016. 480 с.

8. Миллер А. И. «Украинский вопрос» в политике властей и русском общественном мнении (вторая половина XIX в.) : монография. Санкт-Петербург : Алетейя, 2000. 260

9. Присяжнюк Ю. «Праця» як цінність у колективній психології українських селян посткріпосницької епохи (на матеріалах Наддніпрянської України). Україна Модерна. Львів, 2001. Чис. 6. С. 47-58.

10. Донченко О., Романенко Ю. Архетипи соціального життя i політика (Глибинні регулятиви психополітичного повсякдення) : монографія. Київ : Либідь, 2001. 334 с.

11. Бойко Я. В. Заселение Южной Украины. 1860-1890 гг. : монографія. Черкассы : Сіяч, 1993. $256 \mathrm{c.}$

12. Якименко М. Переселенський рух у Наддніпрянській Україні в роки столипінських реформ (1906-1913 рр.) : монографія. Полтава : РВ ПДАА, 2009. 148 с.

13. Присяжнюк Ю. Українське селянство Наддніпрянської України : соціоментальна історія другої половини XIX - початку XX ст. : монографія. Черкаси : «Вертикаль», вид. ПП Кандич С. Г., 2007. 640 с.

14. Литвинова Т. Ф. «Поміщицька правда». Дворянство Лівобережної України та селянське питання наприкінці XVIII - у першій половині XIX століття (ідеологічний аспект) : монографія. Дніпропетровськ : ЛІРА, 2011. 732 c.

15. Вілсон Е. Українці : несподівана нація / пер. 3 англ. Київ : К.I.C., 2004. 552 c.

16. Шамара С. Сільська інтелігенція Наддніпрянської України другої половини XIX - початку XX ст. : соціально-психологічні та етнокультурні характеристики : автореф. дис. ... канд. іст. наук : 09.00.12. Київ, 2008. 20 с.

17. Грушевський М. С. Твори у 50 т. Львів : Вид-во «Світ» 2002. T. 1. С. $376-382$.

\section{References:}

1. Anderson, B. (2001). Uiavleni spilnoty Mirkuvannia shchodo pokhodzhennia y poshyrennia natsionalizmu. [Imagined Communities : Reflections on the Origin and Spread of Nationalism]. Kyiv : Krytyka [in Ukranian].

2. Yakovenko, N. (2006). Dovhe chvertstolittia modernizatsii. [A long quarter of a century of modernization]. Ukrainskyi Humanitarnyi Ohliad - Ukrainian Humanitarian Review. 12, 37-47. Kyiv : Krytyka [in Ukrainian].

3. Shliahov, O. (2008). Tsaryzm ta ekonomicha modernizatsia Ukrainy (druha polovyna XIX - pochatok XX st.). [Czarism and economic modernization of Ukraine (second half of the nineteenth - beginning of the twentieth century)]. Visnyk Dnipropetrovskogo natsionalnogo universytetu. Seriia : Istoriia ta arheologia. 16, 29-39 [in Ukrainian]. 
4. Weber, M. (2018). Protestantska etyka I dukh kapitalizmu. [The Protestant Ethic and the Spirit of Capitalism]. Kyiv : Nash Format [in Ukrainian].

5. Marx, K., Engels, F. (1986). Feierbach. Protivopolozhnost materialisticheskoho i idealisticheskogo mirovozzreniy. [Feuerbach. The opposite of materialist and idealist views]. Selected works in three volumes (Vol. 1, pp. 4-76). Moscow : Politizdat [in Russian].

6. Turchenko, F., Turchenko, H. (2004). Pivdenna Ukraina : modernizatsiia, svitova viina, revolutsia (kinets XIX st. - 1921 r.) : istorychi narysy. [Southern Ukraine : modernization, world war, revolution (end of the nineteenth century - 1921) : Historical essays]. Kyiv : Heneza [in Ukrainian].

7. Kutsyi, I. (2016). Tsyvilizatsiini identychnosti v ukrainskiy istoriohraphii kintsia XVIII - pochatku XX st. : mizh Slovianschynoiu ta Yevropoiu. [Civilizational identities in Ukrainian historiography of the late eighteenth - early twentieth century: between Slavic and European]. Ternopil : Pidruchnyky i Posibnyky [in Ukrainian].

8. Miller, A. (2000). «Ukrainskii vopros» v politike vlastei I russkom obshchestvennom mnenii (vtoraia polovina XIX v.). [«Ukrainian question» in the policy of the authorities and Russian public opinion (second half of the nineteenth century)]. Saint-Petersburg : Aleteiia [in Russian].

9. Prysiazhniuk, Yu. (2001). «Pratsia» yak tsinnist u kolektyvni psycholohii ukrainskykh selian postkriposnyts'koi epokhy (Na materialakh Naddniprianskoi Ukrainy). [«Labor» as a value in the collective psychology of Ukrainian peasants of the post-serfdom era (On the materials of Dnieper Ukraine)]. Ukraina Moderna - Modern Ukraine. 6, 47-58 [in Ukrainian].

10. Donchenko, O., Romanenko, Yu. (2001). Archetypy soctsialnoho zhyttia i polityka. (Hlybynni rehuliatyvy psychopolitychnoho povsiakdennia). [Archetypes of social life and politics (Deep regulations of psychopolitical everyday life)]. Kyiv : Lybid [in Ukrainian].

11. Boiko, Ya. (1993). Zaselenie Yuzhnoi Ukrainy. 1860 $1890 \mathrm{hh}$. [Settlement of Southern Ukraine. 1860-1890]. Cherkasy : Siiach [in Russian].

12. Yakymenko, M. (2009). Pereselenskyi rukh u Naddniprians'kii Ukraini v roky stolypins'kykh reform (1906-1913). [Resettlement move in Dnieper Ukraine during the Stolypin reforms (1906-1913)]. Poltava : RV PDAA [in Ukrainian].

13. Prysiazhniuk, Yu. (2007). Ukrainske selianstvo Naddniprians'kpi Ukrainy : sotsiomental'na istoriia druhoi polovyny XIX - pochatku XX st. [Ukrainian peasantry o f Dnieper Ukraine : sociomental history of the second ha lf of the nineteenth - early twentieth century]. Cherkasy : Vertykal [in Ukrainian].

14. Lytvynova, T. (2011). «Pomishchytska Pravda». Dvorianstvo Livoberezhnoi Ukrainy ta selians'ke pytannia naprykintsi XVIII - u pershii polovyni XIX stolittia (ideolohichnyi aspect). [«Landlord's Truth». The nobility of the Left Bank of Ukraine and the peasant question in the late eighteenth - in the first half of the nineteenth century (ideological aspect)]. Dnipropetrovsk : Lira [in Ukrainian].

15. Wilson, E. (2004). Ukraintsi : nespodivana natsia. [The Ukrainians : Unexpected Nation]. Kyiv : K.I.S. [in Ukrainian].

16. Shamara, S. (2008). Silska intelihentsiia Naddniprianskoi Ukrainy druhoi polovyny XIX - pochatku XX st. : sotsial'no-psycholohichni ta etnokulturni kharakterystyky. [Rural intelligentsia of Dnieper Ukraine in the second half of the nineteenth - early twentieth century : sociopsychological and ethnocultural characteristics]. Abstract of candi-date's thesis. Kyiv [in Ukrainian].

17. Hrushevskyi, M. (2002). Tvory u 50 tomakh. [Works in 50 volumes]. (Volume 1, pp. 376-382). Lviv : Svit [in Ukrainian].
Yu. Prysiazhniuk

\section{UKRAINIAN PEASANTS OF THE EARLY TWENTIETH CENTURY IN THE CONTEXT OF CHALLENGES OF THE COMING ERA: THE INTERNATIONAL ASPECT}

Introduction. Modern humanities scholars recognize that the modern history of Ukrainians, which we understand in its social manifestations, intellectual ideas and interpretations, has undergone radical changes at the turn of the nineteenth and twentieth century. These changes were caused by many factors. It's not a secret that the most powerful of these have been closely linked to global world perturbations.

The revealed historiography of the problem does not allow to fully understand how the rural people of that time were influenced by the policy of the leading states, first of all by the significant strengthening of governmental regulation of the economy, which includes systematic legislative, executive and control measures, which were carried out by state institutions and public organizations in order to stabilize and adapt rural people to the new historical conditions. All this significantly increases the interest of researchers in the peasantry, which in Ukraine accounted for 80-90\% of the population, especially in the context of a significant deepening of the social division of a labor, which then first reached the world scale.

Purpose. The purpose of the reconnaissance is to investigate the impact of changes in the world order, especially in the socio-economic, political and, ultimately, national spheres, on the prospects for the transformation of the peasantry of Naddniprianschyna in the early twentieth century.

Methods. The basis of the methodology of scientific research is an interdisciplinary approach that allows imagining, creating and analyzing the scientific picture of the world; it also helps to identify similarities and differences, as well as features and interactions of countries, peoples, social groups.

Results. The author argues that Ukraine's situation remained difficult and unpredictable. The Russian and Austro-Hungarian empires rejoiced that a "peasant» country with great economic potential, geographically located in the center of Europe, belonged to them at the same time, and what impressed them most was that it did not claim its own national-state self-affirmation. By assigning her the role of a kind of donor to strengthen their imperial ambitions, the "neighbors" did not see her readiness for a rapid national awakening.

Originality. Based on an in-depth analysis of historiography and the actual situation of the village of Naddniprianschyna in the early twentieth century the author claims that the thesis that the life and activity of Ukrainian peasants did not depend on their mental "attachment to the land» is not true. Researchers who hold the opposite view, including the Russian historian Oleksey Miller, in their scientific statements ignore the original factors of ethnic culture, which today are quite thoroughly a studied by modern psychologists. Instead, they artificially and stereotypically impose the idea that the peasants allegedly created a national myth, although, let us recall, this was not their historical mission at all.

Conclusion. At the turn of the twentieth century Ukrainians were still represented mainly by the peasantry, which despite significant reformist successes in terms of capitalization, remained largely traditional in its culture and mental essence. The author considers that almost the only worthy answer to the question of international recognition of Ukrainians was detined to be national-state progress.

Key words: geopolitics, historiography, mentality, ethnic identity, peasant nation, traditional society, modernization. 